\title{
Macroeconomic Impact of Foreign Direct Investment in Sri Lanka
}

\author{
A. M. M. Mustafa
}

\begin{abstract}
This research is aimed at tracing the impact of Foreign Direct Investment (FDI) in promoting macroeconomic variables such as gross domestic production, industrial production, total domestic investment, exports, imports, Board of Investment approved exports, Board of Investment approved imports and Board of Investment approved employments by using the time series annual data for 1978 - 2018 in Sri Lanka. Multiple Regression Analysis was used to estimate the impact of FDI on selected macroeconomic variables. Estimation method was Ordinary Least Squares. EViews 10 software were used for data analysis. The empirical evidence shows that there is a statistically significant positive impact of FDI on selected macroeconomic variables except in the case of imports. However, this study further reveals that the actual impact on macroeconomic variables can be felt after certain time lag. But the impact on total domestic investment was realized immediately. Further, this research has identified various problems faced in attracting FDI including ideal sector identification and the appropriate recommendations have been presented in order to realize the major benefits from FDI inflow into the country.
\end{abstract}

Keywords : FDI; Gross Domestic Production; Industrial Production; Total Domestic Investment; Exports; Imports; Employments.

\section{INTRODUCTION}

Foreign Direct Investment has been one of the defining features of the world economy over the past three decades. Firms in all level of industries are expanding internationally with foreign direct investment than ever before. The past three decades has witnessed a large opening and modernization of economies in every region, encompassing deregulation, de-monopolisation, privatization, and reduction and simplification of tariffs to attract FDI. In this regard, there are number of theories explaining foreign direct investment and its features. Most of the theories are based on attracting FDI into a country. These theories were formulated to provide ideas and policies to implement FDI strategies as FDIs are capable of influencing on gross domestic product of countries significantly. While FDI can be directly attracted by trade, production, local infrastructure development and tourism that lead to economic growth of a country. Theoretically, FDI can affect the host economy at both macro

Revised Manuscript Received on September 25, 2019

Dr.A. M. M. Mustafa, Senior Lecturer in Business Economics, Department of Management, Faculty of Management and Commerce, South Eastern University of Sri Lanka,Oluvil,\#32360, Sri Lanka and micro levels. At the micro level, FDI may influence the technical and management efficiency of joint ventures and local firms through technology transfer, labor training and spill- over effects.

At the macro level, FDI may affect both, macroeconomic variables such as economic growth, domestic investment, employment, exports and imports and financial variables such as interest rates, foreign exchange rate, inflation level, and balance of payments (Sun,1998). However, this research mainly focuses on the macroeconomic variables. There has been an increasing trend in most of the macroeconomic variables in Sri Lanka. In this context, the variables which have been taken to this particular study also shows the increasing trend on total domestic investment, exports, imports, employment and Sri Lanka had better economic growth in the post - 1977 period. Hence, the role of this study is to find the contribution of FDI towards the particular macroeconomic variables. When considering the results of the previous FDI analyses, there is an urgent need to host countries to invite FDI, commonly; countries try to address economic problems. Sri Lanka also hosts FDI in this context. Economic growth and development is vital to Sri Lanka as it is a developing country with the socio-economic problems such as lack of investment, low local savings for a long time, deficit balance of payment, lack of savings and capital, expertise problem, problems in international marketing, increase in unemployment rate, unutilized resources, lack of capacity, lack of saving, scarcity of foreign exchange and poor technological ability. FDI is one of the solutions to overcome these problems. This study aims to investigate the impact of FDI on macroeconomic variables in Sri Lanka for the twenty-seven years. The focus is mainly centered on the effects of FDI on real macroeconomic variables such as Gross Domestic Product, Total Domestic Investment, Exports, Imports and Employment.

\section{REVIEW OF LITERATURE}

Researches related to FDI have increased Worldwide. researchers have done researches in FDI and 
Macroeconomic variables. Especially, Sun (2001) in China, investigated the macroeconomic impact of FDI in the past two decades with concentration on the effect of FDI on real macroeconomic variables, and found that FDI has positive impact on domestic investment and economic growth. Agrawal (2000) examined economic impact of FDI in South Asia, he found a positive correlation between FDI and economic growth. Jansen (1995) focused on the macroeconomic effects of FDI in the case of Thailand. He found that the export oriented FDI is likely to have a positive effect on private investment and GDP growth. Balasubramanyam et al. (1996) examined, within a new growth theory framework, the role which FDI plays in the growth process in the context of developing countries characterized by differing trade policy regimes. Kohpaiboon (2000) examined the role of trade policy regimes in conditioning the impact of FDI on growth performance in investment receiving host countries through a case study of Thailand. Borensztein et al. (1998) found that FDI is an important vehicle for the transfer of technology, contributing relatively more to growth than domestic investment, the research carried out cross-country study of 69 developing countries, he also found that a positive but insignificant impact on growth. Chakraborty \& Basu (2003) examined the causal relationship between FDI and economic growth by using an innovative econometric methodology to study the direction of causality between the two macroeconomic variables. Sahoo \& Mathiyazhagan (2003) investigates the role of FDI in promoting the growth of the economy via export promotion in India.

Khan \& Leng.(1997) examined interactions among these three important macroeconomic variables (FDI, export and growth) in Korea, Singapore and Taiwan and they argued that free trade policy launched Singapore on a high growth path that took the country out of the developing country category. Sharma (2000) investigated the determinants of export performance in India and suggest that demand for Indian export increases when its export prices fall in relation to world prices. Soliman (2003) examines the effect of FDI activity on manufacturing exports in four MENA countries and finding of this analysis suggest that FDI activity may have a positive effect on the host country's manufacturing exports. Wilamoski \& Tinkler. (1999) examines the effects of U.S FDI in Mexico on U.S export to and imports from Mexico. Ancharaz (2003) examines the impact of FDI on the country's export performance and export competitiveness. It argues that, while FDI has been instrumental is export development, it has not had much of an impact on export competitiveness. Leichenko et al.(1997) assesses the effects of FDI on the manufacturing export performance of U.S states and result indicate that increased. Lemi (2004) the purpose of this study is to analyze the role that FDI from the U.S. and Japan plays in affecting developing countries' productivity, and export and positive productivity effects from U.S. and Japanese FDI firms are not empirically supported for the case of sample developing countries. The objective of the research done by Andersen \& Hainaut. (1998) was to look for evidence regarding the precise relationship between FDI and employment in the source countries and found only limited evidence that FDI lead to job losses in the source countries. Jahur \& Rabbanee.. (2002) FDI has been found to have significant and positive impact on the employment generation in Bangladesh. $\mathrm{Fu} \&$ Balasubramanyam (2005) analyses the growth of production and employment in China and It argues that the Chinese experience with export-led growth provides an excellent case study of the phenomenon of a vent for surplus resources provided by exports. Agosin \& Mayer (2000) assessed the extent to which FDI in developing countries crowds in or crowds out domestic investment and results indicate that in Asia-but less so in Africa- there has been strong crowding in of domestic investment by FDI. Sugandh (2018) evaluates evidence of the Foreign Direct Investment an Analysis of Indian Economy. The objective of this paper is to study the role of Indian Government to attract FDI and to analyse the trend to FDI inflows in the Indian economy. The paper also highlights the effects of FDI on host country.

Mostly, the above literatures have been done empirically and have benefited the countries concerned. This has been studied empirically and has benefited to the above countries. Most of the researches have been done on the basis of understated manner. In those literatures, Technology was an exogenous factor in the neoclassical framework, remained a dominant paradigm in economics for a long time. However, with the emergence of new growth theories knowledge - induced growth has become one of the focal points of research in economics. Endogenous growth was recently combined with studies on the diffusion of technology in an attempt to emphasize the major role played by FDI in economy. However, in Sri Lanka, there are few researches. Athukorala (1995), in his study on "The Relationship between Trade and Export oriented FDI" and found that much of the export dynamism experienced is due to foreign investment. Wilhelms (1998), in there, "FDI and the determinants in emerging economies", they included Sri Lanka. Institute of Policy study of Sri Lanka (2000) explained FDI and economic integration in SAARC region; Fernando (1996) explained FDI in Sri Lanka - Directions for Policy. Nisantha (2000) had done a study on 
Liberalization and FDI in a small developing country - The case of Sri Lanka - and its objective was to promote the process of FDI and Multinational Companies (MNCs) development in Sri Lanka. Athukorala (2003) analysed the Impact of Foreign Direct Investment for Economic Growth in Sri Lanka and the main objective was to consider the short run and long run relationship between FDI and economic growth. Nevertheless, in Sri Lanka, the study on "FDI and macroeconomic variables" has not been done yet. This proposed research has been made to investigate the relationship between FDI and macroeconomic variables in Sri Lanka econometrically and descriptively. Therefore, this study will fill the research gap between FDI and macroeconomic variables in Sri Lanka.

\section{METHODOLOGY}

The study covers the period 1978-2018. Data relevant to this study will be collected from the secondary sources such as International Financial Statistics (IFS), World Investment Report 1990-2018, Investors Guide and Central Bank Annual Report 1978-2018.In this study, Econometric Methodology - Multiple Regression and Correlation analysis will be used to analyze the data and Ordinary Least Square (OLS) method is used to estimate the parameters of the model. Granger type causality test will be used to identify the direction of casual relationship between selected macroeconomic variables and Unit root test will be applied to test stationary properties of each variable. Co-integration analysis will be done to examine the long run (LR) relationship between FDI and selected macroeconomic variables. Eviews and Excel statistical software used for the data analysis.

\section{ANALYTICAL FRAMEWORK}

These analytical functions given below test the data contributed to performance of economy as a whole and with specific to BOI Enterprises.

\section{Gross Domestic Product Function:}

Based on the above discussion, the model to investigate the relationship of FDI and economic growth derived by using the production function framework. The starting point of model formulation is the aggregate production function.

$Y=f(A, K, L) \ldots \ldots \ldots \ldots \ldots \ldots \ldots \ldots(1)$

Where $\mathrm{Y}$ is output (Gross Domestic Product), L is labour input and $\mathrm{K}$ is capital. The variable A captures the total factor productivity (TFP) of growth in output not accounting for increasing in factor inputs ( $\mathrm{K}$ and $\mathrm{L}$ ). According to the new endogenous growth theory, $\mathrm{A}$ is endogenously determined by economic factors. However, by making the reasonable assumption that the method of estimating FDI has been consistent over the years, the effect of FDI on economic growth operating through A. Further, the effect of FDI on A also depends on the trade policy regime. Hence, the trade policy regime (TP) needs to be incorporated in equation (Kohpaiboon, 2000).

$$
G D P=f(F D I, F D I * T P, D I, L F)
$$

Here GDP stands for gross domestic product, DI domestic investment, FDI for foreign direct investment, and LF for labour force.

\section{Industrial Production Function:}

$I P=f\left(F D I, L I_{B}, \operatorname{Emp}_{B}\right) \ldots \ldots \ldots \ldots \ldots \ldots \ldots \ldots(1)$

Where IP for Industrial production, FDI for foreign direct investment, $\mathrm{LI}_{B}$ for Local investment of BOIE, Emp ${ }_{B}$ for Employment of BOIE.

\section{Total Domestic Investment Function:}

This model, based on Sun (1998), formulates model to examine the impact of FDI on Sri Lankan's domestic investment, which is taken as a function of FDI, income per capita, foreign capital and exchange rate. Thus, for propose of this study the domestic investment function is given as follow:

$T D I=f(F D I, G D P P C, R E X, I R)$

Where TDI is the total domestic Investment, GDPPC is the per capita income, FDI is foreign direct investment, REX is the real exchange rate and IR interest rate.

\section{Total Investment Function (BOI Enterprises):}

$T I_{B}=f(F D I, G D P P C, R E X, I R) \ldots \ldots \ldots \ldots \ldots \ldots(1)$

Where $\mathrm{TI}{ }_{B}$ is the Total investment of BOIE, FDI is foreign direct investment; REX is the real exchange rate and IR interest rate.

\section{Exports Function:}

FDI has impact on exports as with other variables. To test this, based on Wilamoski et al. (1999), the export supply function is specified as:

$X=f(F D I, D I, L F, R E X) \ldots \ldots \ldots \ldots \ldots \ldots \ldots \ldots \ldots \ldots(1)$

Where $\mathrm{X}$ is the export, DI is the domestic investment, FDI is foreign direct investment, FK is foreign investment other than FDI, $\mathrm{L}$ for Labour force and REX is the real exchange rate.

\section{Exports Function (BOI Enterprises):}

$$
X_{B}=f\left(F D I, L I_{B}, E_{m p}, R E X\right) \ldots \ldots \ldots \ldots \ldots \ldots \ldots . .(1)
$$


Where $\mathrm{X}{ }_{B}$ is the export of BOIE, FDI is foreign direct investment, $\mathrm{LI}_{B}$ is Local investment of BOIE, Emp $\square_{B}$ for Employment of BOIE and REX is the real exchange rate.

\section{Imports Function:}

The import function is specified as:
Employment creation is an important positive impact of FDI though several factors determine the same. For many countries having a large portion of unemployed, the criterion of employment takes the lead on agenda. The employment equation for the purpose of this study is formulated as:

$E m p=f(F D I, D I, X)$

$M=f(F D I, D I, G D P P C, R E X)$

Here Emp stands for employment, FDI for foreign direct (1) nvestment, DI is domestic investment and X for exports.

Where $\mathrm{M}$ is the import, FDI is foreign direct investment, DI is the domestic Investment and REX is the real exchange rate. The import demand function is based on the traditional theory of demand, where the quantity demanded is expressed as total imports.

\section{Imports Function (BOI Enterprises):}

$M_{B}=f\left(F D I, L I_{B}, R E X\right)$

Where $\mathrm{M}_{B}$ is the import of BOIE, FDI is foreign direct investment, $\mathrm{LI}{ }_{B}$ is the Local investment of BOIE and REX is the real exchange rate.

Employment Function:

\section{Employment Function (BOI Enterprises):}

$E m p_{B}=f\left(F D I, L I_{B}, X_{B}\right)$

Where $E m p_{B}$ is the Employment of BOIE, FDI is foreign direct investment, $\mathrm{LI} \square_{B}$ is the Local investment of BOIE and $\mathrm{X}{ }_{B}$ for export BOIE.

In Regression analysis the Log - Log model selected by considering the results of the adjusted $R^{2}$, the estimated $\mathrm{F}$ value, probability value, Durbin-Watson (DW) D statistics and Variance inflating factor (VIF).

\section{RESULT AND DISCUSSIONS}

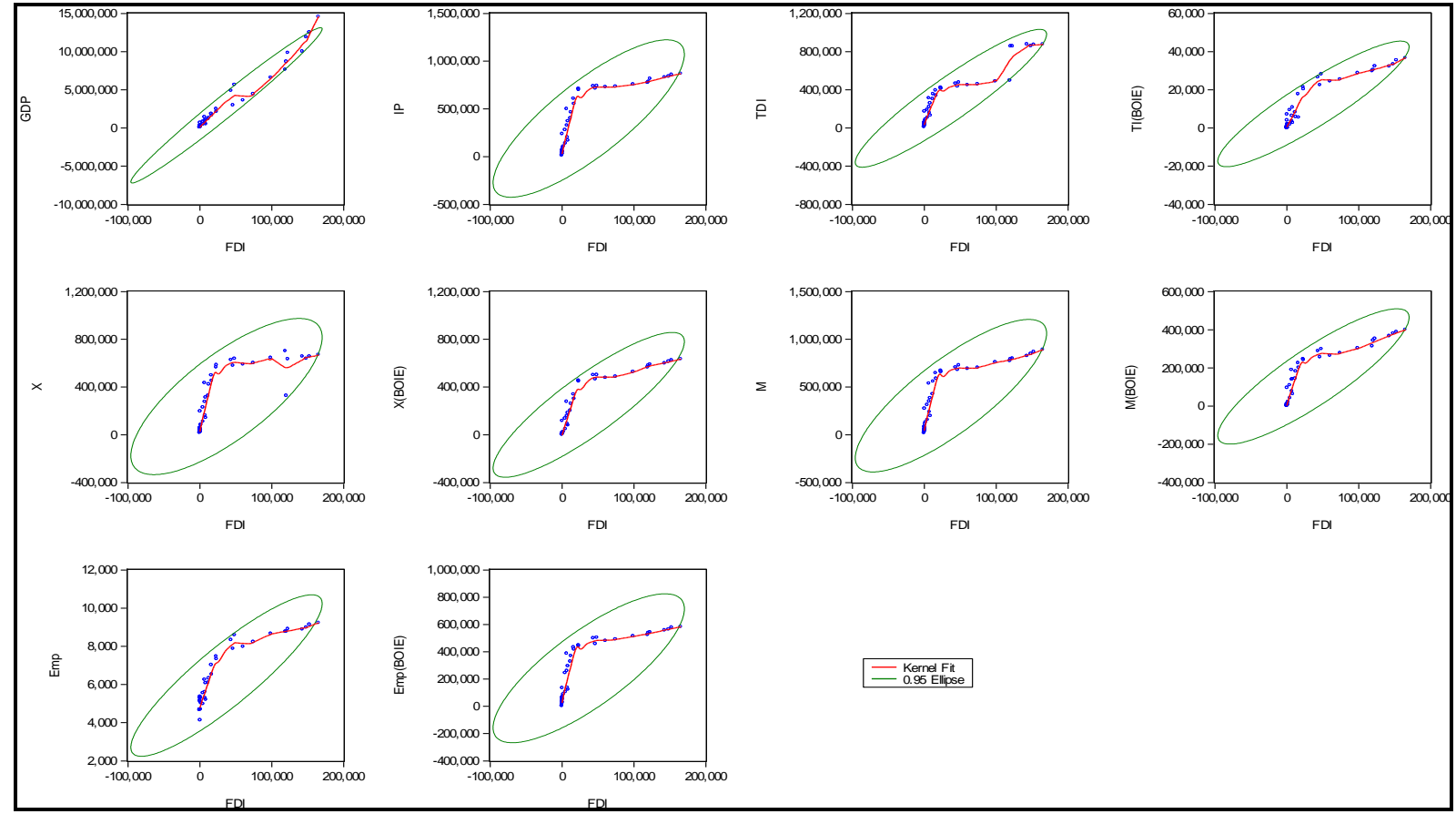

Figure 1 - Kernel Fit with Confidence ellipse

Below Graphical presentation of data is very useful to identify the trend and underlying relationship between the variables GDP: FDI, IP:FDI, TDI:FDI, TI(BOIE):FDI, X:FDI,X(BOIE):FDI ,M:FDI, M(BOIE):FDI, EMP:FDI and EMP(BOIE):FDI. The Kernel Fit and Confidence ellipse graphs show that strong positive relationship between the variables. And also show series are correlated.
Regression Results for the Model - Gross Domestic Product Function: According to the regression output presented in adjusted $R^{2}$ is very high, F-statistic and Prob. (F-statistic) are appropriate. The coefficient of determination of all the independent variables of $92 \%$ implies that the selected independent 
variable explain $92 \%$ of the total variation in GDP thus validating the statistical appropriateness to measure the relationship between economic performance and factors which affect the economic performance specially FDI. The model is overall significant at $1 \%$ level. Further regression output presented in reveals that all the sign of coefficient of the variables are as theoretically expected, further, the estimated coefficient of FDI indicates that, $1 \%$ increase in changes of FDI will increase GDP only by 1.12 $\%$. The relationship between FDI and GDP has been positively and statistically significant at 5\% level. However, it reveals that the actual impact of FDI can be felt after certain time lag of two years.

Regression Results for the Model - Industrial Production Function: The results of the estimated model which explains that specified model performed very well in terms of F-Statistics. The results describe that model is highly significant. $\mathrm{R}^{2}$ the coefficient of determination explains how much linear relationship has the dependent variable with independent variables. The value of $R^{2}$ is 0.94 at $1 \%$ significant level, which explains that $94 \%$ variation in the GDP is explained by the independent variables. This statistical appropriateness to measure the relationship between economic performance and factors which affect the economic performance especially FDI. further, the estimated coefficient of FDI indicates that $1 \%$ increase in changes in FDI will increase IP only by $0.82 \%$. Therefore, the relationship between FDI and IP has been positively and statistically significant at 5\% level. However, it reveals that the actual impact of FDI can be felt after a certain time lag of one year.

Regression Results for the Model - Total Domestic Investment Function: the regression output to total domestic investment function presented very high adjusted $R^{2}$ and this model performed well in F-statistic, Prob. (F-statistic). Because both are appropriate. The coefficient of total domestic investment of $95 \%$ at the $1 \%$ significant level implies that the selected independent variable explains $95 \%$ of the total variation in TDI to estimate the relationship between TDI which affect the economic performance of FDI and FDI. Further, findings of the research reveal that all the sign of the coefficient of the variables is as same as theoretically expected. Further, the estimated coefficient of FDI indicates that a $1 \%$ increase in changes of FDI will lead to increase TDI by $0.362 \%$ only. The impact of FDI on total domestic investment was realized immediately. As well as, the relationship between FDI and IP has remained positively and statistically significant at $1 \%$ level.

Regression Results for the Model -Total Investment Function (BOI Enterprises): This model show that the adjusted $R^{2}$ is very high and F-statistic, Prob. (F-statistic) are also well in this regression model. The coefficient of TI (BOIE) of $96 \%$ implies that the $96 \%$ of the total variation in $\mathrm{TI}(\mathrm{BOIE})$. Therefore, this result explain that there is relationship between TI (BOIE) and FDI. The model shows the $1 \%$ overall significant level. The output reveals that all the sign of coefficient of the other variables are theoretically expected. Coefficient of FDI indicates that, $1 \%$ increase in changes of FDI will increase TI (BOIE) only by $1.61 \%$. FDI has the positive and $1 \%$ significant relationship with TI (BOIE). Even though, this research reveals that the actual impact of FDI can be felt after certain time lag of one years.

Regression Results for the Model - Exports Function: The results of the model which reveals that estimaed model performed very well in terms of F-Statistics and probability value. And also, The results describe that model is highly significant at $1 \% . \mathrm{R}^{2}$ the coefficient of export explain that there is relationship between the FDI and export. The value of $R^{2}$ is 0.96 which explains that $96 \%$ variation in the FDI is explained by the independent variables. Further, the estimated coefficient of FDI indicates that, $1 \%$ increase in changes of FDI will lead to increase export only by $2.3 \%$. The long run relationship between FDI and $X$ is positive and significant at 5\% level. However, export reveals that the actual impact of FDI can be manipulated after certain time lag of two years.

Regression Results for the Model - Exports Function (BOI Enterprises): According to the findings adjusted $R^{2}$, F-statistic and Prob. (F-statistic) are performed very well. The coefficient of determinants of all the independent variables of $97.3 \%$ explains that the selected independent variable explain $97.3 \%$ of the total variation in $\mathrm{X}(\mathrm{BOIE})$ thus validating the statistical appropriateness to estimate the relationship between economic performance and factors which affect the economic performance of FDI. The model is overall significant at $1 \%$ level. Further, output reveals that all the sign of coefficient of the variables are as theoretically expected. The estimated coefficient of FDI explains that, $1 \%$ increase in changes of FDI will increase $\mathrm{X}(\mathrm{BOIE})$ by $2 . .43 \%$. This model is positively related between FDI and $\mathrm{X}(\mathrm{BOIE})$ in the long run and this result is statistically significant at $1 \%$ level. However, finding explains that the 
impact of FDI can be felt after certain time lag of two years.

Regression Results for the Model - Imports Function: According to the regression model represented in adjusted $R^{2}$ is very high, F-statistic, Prob. (F-statistic) are appropriate. The coefficient of determinants of all the independent variables of $91 \%$ implies that the selected independent variable explain $91 \%$ of the total variation in import thus validating the statistical appropriateness to measure the relationship between economic performance and factors which affect the economic performance specially FDI. FDI and $\mathrm{M}$ has been positively and statistically not significant.

\section{Regression Results for the Model -Imports} Function (BOI Enterprises): Regression results for the imports explains that adjusted $R^{2}$ of this model is very high. And also, F-statistic, Prob. (F-statistic) are performed very well in this model. The coefficient of all the independent variables of $95 \%$ implies that the selected independent variable explain $95 \%$ of the total variation in $\mathrm{M}(\mathrm{BOIE})$ by validating the statistical appropriateness to measure the relationship between economic performance and factors which affect the economic performance of FDI. The model is overall significant at $1 \%$ level. Further, output reveals that all the sign of coefficient of the variables are as theoretically expected. The estimated coefficient of FDI indicates that, $1 \%$ increase in changes of FDI will increase $\mathrm{M}(\mathrm{BOIE})$ by $3.42 \%$. The long run relationship between FDI and $\mathrm{M}$ (BOIE) has positive and statistically significant at $10 \%$ level. However, output reveals that the actual influence of FDI can be manipulated after certain time lag of two years.

Regression Results for the Model -Employment Function: According to the regression output, adjusted $R^{2}$ is very high. F-statistic, Prob. (F-statistic) are appropriate. The coefficient of all the independent variables of $92 \%$ at $1 \%$ level shows that the selected independent variable explain $92 \%$ of the total variation in EMP thus validating the statistical appropriateness to estimate the relationship between economic performance and factors. Further regression output expalins that all the sign of coefficient of the variables are like as theoretically expected. The estimated coefficient of FDI indicates that, $1 \%$ increase in changes of FDI will increase EMP only by $0.29 \%$. The relationship between FDI and EMP has been positively and statistically significant at $10 \%$ level. However, output reveals that the actual impact of FDI can be felt after certain time lag of one years.
Employment Function (BOI Enterprises):

Regression output presented in adjusted $R^{2}$ is high and F-statistic and Prob. (F-statistic) are appropriate. The coefficient of determinants of all the independent variables of $94 \% \quad 1 \%$ level reveals that the selected independent variable implies $94 \%$ of the total variation in EMP(BOIE) to measure the relationship between economic performance and factors which affect the economic performance specially FDI. Further regression output reveals that all the sign of coefficient of the variables are as theoretically expected. And the estimated coefficient of FDI indicates that, $1 \%$ increase in changes of FDI will increase EMP (BOIE) only by $1.06 \%$. The relationship between FDI and EMP (BOIE) has been positively and statistically significant at 5\% level. However, it explains that the actual impact of FDI can be felt after certain time lag of two years.

\section{CONCLUSION}

Globalization process integrates all countries by transforming into an international village and it creates the interdependence of world's economies, cultures, information, technologies and flows of investment etc. Hence, foreign direct investment change as an important tool to face present and future challenges. It is shown by the continuous increase in foreign direct investment in recent decades. Foreign direct investment plays a vital role in the inflow of investment and developing process of an economy. Further, it contributes to the gross domestic product and export through the increase in domestic capital. Direct investment expands national economic activities by creating employment opportunities and new technological intervention. Therefore, this research aims to find the impact of foreign direct investment on macroeconomics determinants. Namely, gross domestic production, industrial production, total domestic investment, exports, imports, Board of Investment approved exports, Board of Investment approved imports and Board of Investment approved employments. This research is explained by the secondary data which are collected from the secondary sources and used the second time series data over the period of time 1978 to 2018. Collected data are analyzed by using the Ordinary Least Square Model (OLS) in multiple regression. Further, research is fitted the separate models to analyze the impact of foreign direct investment on each and every macroeconomics variables.

According to the findings of multiple regression of this research, it is found that gross domestic product, industrial production,total domestic investment, Board of 
Investment total domestic investment, export, board of investment export, board of investment import, employment and Board of Investment employment are relationship with the foreign direct investment positive and statistically significant in Sri Lanka except the import. Moreover, this research is estimated that there is a statistically significant and positive correlation between foreign direct investment and other macroeconomic variables.According to the result of this research, foreign direct investment has an immediate impact on total domestic investment. But, foreign direct investment statistically impacts on other macroeconomic variables after a certain number of years. Results of this research shows that FDI has the positive impact on selected macroeconomic variables of this research by increasing the efficiency of products in domestic sectors and efficient resource allocation through the technological transformation, labour and capital movements between the sectors, expansion of harbors, the fall in Balance of payment crisis, creating international market and employment opportunities, connectivity with the domestic economy, improvements of export, import, management skills and technological and creating labours with the technical skills. Even macroeconomic variables have a positive impact on FDI, they show the differences in the time periods for positive impact between the variables. Therefore, the government want to take actions on the priority basis to use the FDI.

\section{Recommendations}

This research suggests the recommendation based on the results of the fifth chapter and possible sectors to attract the foreign direct investment inflows and problems faced by the foreign direct investors which are identified based on the econometrics output.In Sri Lanka, to increase the contribution of FDI on GD, the government want to attract the FDI for the development of human resource skills such as the service sector. Sri Lanka has the possible land resources and weather to cultivate the herbal and flowers. Hence, Sri Lanka tries to promote the agricultural sector through modern techniques.Almost there is research institute for the coconut, tea and rubber in Sri Lanka. Nevertheless, FDI can be expanded the technical effectiveness of the institutes. Therefore, Sri Lanka can obtain expertise in the agriculture sector from agricultural specialized countries. Moreover, even Sri Lankan investors are capable of fishery and animal husbandry, they need additional expertise. Further, total GDP can be increased by connectivity FDI through the deep-sea and freshwater fishery and export of colour fishes.
Research findings indicate the importance of FDI to increase industrial production. Future, FDI policy should be designed to diversify the domestic industry. Sri Lanka has an opportunity to rank of newly industrialized country by identifying and promoting the following things: investments should be attracted according to the intellectuals of the country. Moreover, political stability, developing the infrastructure, promoting the technological and technical skills of labours, purchasing the raw materials in the global market price and attracting the national and international foreign direct investors can promote Sri Lanka as a newly industrialized country. FDI policies should be made to increase the total domestic investment opportunities through the attracting FDI inflows. Policies should be in their own language of foreign investors. They could read and easily understand the policies which are related to the FDI in Sri Lanka. Through a large amount of FDI inflows can be attracted to increase the total domestic investment.

According to the findings, Sri Lanka has to plan the programs to increase the inflow of the FDI on employments and to stop the domestic professional and intellectual migrations. Specially, their salary should be decided based on the exchange rate and additional facilities should be given. If a country needs the FDI contribution, it must be capable of inviting the technological-based FDI. For that, there should be a group of intellectuals. In Sri Lanka, labour incentive technology is used paper and wood productions. When these sectors were improved by FDI, it would increase the employment level.Establishing labour unions through FDI programs was a big challenge in Sri Lanka. Even though the Government has the authority to stop those labour unions in these investment programs, it is practically impossible. Hence, establishing an organization is important to solve the problems and challenges among the employee and the employer.

Creating a network among industries should be build up to improve the technological and managerial techniques network among the universities. Further, vocational institution, research institutes, foreign universities also are connected and create suitable employment opportunities for the FDI inflows. A company which is authored by the investment board should offer more than 250 employment opportunities or else 5000 employment should be given for a billion rupees investment. Moreover, suitable training should be given to the employees to fit the technological which were can through FDI.Withdrawal of textile 
quota from the FDI leads the country to compete with the other countries in the international market. So, to retrain from this hazard following two strategies can be used. First, doing the fashion design which the help of foreign expertise. Second, getting an agreement from the internationally famous textiles producers. Improve this sector through FDI would expand the export of this sector. If the products which were produced by the FDI would be able to export to more than 3 countries. ait would help to obtain the worldwide market opportunities to the country.Exporters were authorized by the investment board to sell $10 \%$ of the products in the domestic market. Through, these local people were able to get the export quality products. Moreover, it helps limit these kinds of imports. So, If we facilitate to sell $20 \%$ of export quality products in the country it would reduce the imports and lead to increase in FDI

\section{REFERENCES}

1. Agosin, M.R. \& R. Mayer. 2000. Foreign Investment in Developing Countries: Does it Crowd in Domestic Investment?, Santiago: Department of Economics, University of Chile. Available at :http://ideas.repec.org/p/unc/dispap/146.html

2. Agrawal, P. 2000. Economic Impact of Foreign Direct Investment in South Asia. India: Indra Gandhi Institute of Development Research. Available

:http://rru.worldbank.org/Documents/PapersLinks/1111.pdf

3. Andersen, P.S. and P.Hainaut. 1998. Foreign Direct Investment and Employment in the Industrial Countries. Switzerland: • Monetary and Economic Department, Basle. Available at :http://www.bis.org/publ/work61.htm

4. Athukorala, P. 1995. "Foreign direct investment and manufacturing for export in a new exporting country: The case of Sri Lanka." World Economy.18:543-564.

5. Athukorala, P.P.A.W. 2003. The Impact of Foreign Direct Investment for Economic Growth: A Case Study in Sri Lanka, 9th International conference on Sri Lanka studies, Matara. Available at :www.freewebs.com/slageconr/9thicslsflpprs/fullp092.pdf

6. Balasubramanyam, V.N., M. Salisu \& D. Sapsford.1996. Foreign Direct Investment and Economic Growth in EP and IS Countries. The Economic Journal, 106 (Jan): 92-105.

7. Borensztein,E., J. De Gregorio \& J.W. Lee. 1998. How does Foreign Direct Investment affect Economic Growth? Journal of International Economics. 45: 115-135.

8. Chakraborty, C. \& P. Basu. 2003. Foreign Direct Investment and growth in India: A cointegration approach, Routledge. Available at : http://www.tandf.co.uk/journals

9. Fernando, R. 1996. Foreign Direct Investment in Sri Lanka: direction for policy. Sri Lanka Journal of Management. 1(4): 312-340.

10. Fu, X. and V.N. Balasubramanyam. Exports, Foreign Direct Investment and Employment: The Case of China. FED Working Papers Series No. FE20050035. Available at :www.fed.org.cn

11. Institute of Policy Studies of Sri Lanka. 2000. Foreign Direct Investment and Economic Integration in the SAARC Region. Colombo. Available :http://www.saneinetwork.net/pdf/SANEI_I/SAARCregion.PDF

12. Jahur, M.S. and F.K. Rabbanee. 2002. Foreign Direct Investment and its Impact on Employment Generation for the Youth- A Study of Chittagong Export Processing Zone of Bangladesh. Riyadh, KSA: Paper for presented in the 9th International Conference on Muslim Youth and Globalization.

13. Jansen, K. 1995. The Macroeconomic Effects of Direct Foreign Investment : The Case of Thailand. World Development.23(2): 193210.

Available

:http://ideas.repec.org/a/eee/wdevel/v23y1995i2p193-210.html
14. Khan, H. \& K.B. Leng. 1997. Foreign Direct Investment, Export and Economic Growth in the three Dragon: Evidence from co integration and causality test. The Singapore Economic Review. 42(2): 40-60.

15. Kohpaiboon, A. 2000. Foreign Trade Regime and FDI- Growth Nexus: A Case Study of Thailand. Research School of Pacific and Asian Studies. Australian National University. Available at :http://rspas.anu.edu.au/economics/publish/papers/wp2002/wp-econ2002-05.pdf

16. Leichenko, M.R. \& A.R. Erickson. 1997. Foreign Direct Investment and State Export Performance. Journal of Regional Science.37(2): 307-329

17. Lemi, A. 2004. Foreign Direct Investment, Host Country Productivity and Export: The case of US and Japanese Multinational Affliates. Journal of Economic Development 163 29(1) . Available at :http://jed.econ.cau.ac.kr/newjed/full-text/29-1/Adugna_Lemi.pdf

18. Nishantha, J.A.T.D. 2000. Liberalization and FDI in a small Developing Country - The Case of Sri Lanka. Available at :http://web.kyoto-inet.or.jp/people/nishan/ronbn/keieiron-engl.htm

19. Shaoo, D. \& M. Mathiyazhagan. 2003, Economic Growth in India: Does Foreign Direct Investment Inflow Matter? The Singapore Economic Review. 48(2): 157-171.

20. Sharma, K. 2000. Export Growth in India: Has FDI Played a Role?, Centre Discussion PaperNo.816. New Haven,Connecticut 06520-8269. Available at : http://www.econ.yale.edu/ egcenter/

21. Soliman, M. 2003. Foreign Direct Investment and LDCs Exports: Evidence from the MENA Region. American University of Sharjah. Available at http://www.erf.org.eg/tenthconf/Trade_Background/Soliman.pdf

22. Sun, H. 1998. Macroeconomic Impact of direct Foreign investment in China: 1979-1996.UK: Blackwell Publishers Ltd.

23. Sun, H. 2001. Foreign Direct Investment and Export Performance in China. Journal of Regional Scienc. 41(2): 317-336

24. Sugandh,M.(2018). Foreign Direct Investment An Analysis of Indian Economy.International Journal of Trend in Scientific Research and Development. Volume 2, Issue 6

25. Wilamoski, P. \& S. Tinkler. 1999. The Trade Balance Effect of US Foreign Direct Investment in Mexico. Atlantic Economic Journal. 27(1): 24-37

26. Wilhelms, S.K.S. 1998. Foreign Direct Investment and its Determinants in Emerging Economies. African Economic Policy Paper. Available at : http://www.eagerproject.com/discussion9.shtml 